\title{
Anal Cancer pT4 TNM Finding v8
}

National Cancer Institute

\section{Source}

National Cancer Institute. Anal Cancer pT 4 TNM Finding v8. NCI Thesaurus. Code C133778.

Anal cancer with tumor of any size invading adjacent organ(s), such as the vagina, urethra, or bladder. (from AJCC 8th Ed.) 